\title{
Caracterización superficial de distintos materiales de construcción
}

\section{Superface energy of several construction materials}

\author{
$\underline{\text { J. Rubio }}^{(*)}$, M. $^{\text {a }}$ J. Sánchez(*), M.a R. Elvira(*), F. Rubio(*), J. L. Otero(*)
}

\section{RESUMEN}

En este trabajo se ha realizado la caracterización de la superficie de diferentes materiales de construcción (mármol, arenisca, granito y ladrillo) mediante cromatografía inversa gas-sólido a dilución infinita. La energía superficial se puede dividir en dos componentes: dispersiva y ácido-base. Los valores obtenidos para la energía dispersiva son bastante parecidas para mármol, granito y ladrillo, mientras que el valor más alto corresponde a la arenisca. Además, este material presenta una menor variación de la energía dispersiva con la temperatura lo que indica que la interacción de cualquier sustancia con su superficie se dará a cualquier temperatura. Por lo que respecta a las componentes ácido-base, se ha observado que todos los materiales poseen ambas componentes lo que indica un carácter anfótero, sin embargo, la acidez es mayor en el granito y en el ladrillo, mientras que la basicidad es mayor en la arenisca y en el mármol.

Palabras clave: materiales de construcción, energía, superficie, cromatografía, caracterización.

\section{SUMMARY}

Inverse gas chromatography at infinite dilution was used to characterize the surface of different construction materials (marble, sandstone, granite and brick). Surface energy can be divided into two components: dispersive and polar or acid-base. The highest dispersive energy value was found for sandstone, while the values for the other three materials were all very similar. The lower dispersive energy variation exhibited by sandstone with temperature changes is an indication that substances interact equally well with its surface at any temperature. All the materials were found to be amphoteric, with both acid and alkaline components, although acidity was greater in granite and brick and sandstone and marble had higher alkalinity.

Keywords: construction materials, energy, surface, chromatography, characterization.

\section{INTRODUCCIÓN}

En los últimos años se están llevando a cabo restauraciones de los monumentos pétreos del Patrimonio Arquitectónico Español con el fin de evitar su deterioro. Entre

\section{INTRODUCTION}

Historic stone buildings and monuments in Spain have been undergoing restoration in recent years to prevent the deterioration of the country's architectural heritage.

(*) Instituto de Cerámica y Vidrio (CSIC), Madrid (España).

Persona de contacto/Corresponding author: jrubio@icv.csic.es (J. Rubio). 
estas actuaciones están las de restauración, conservación, rehabilitación, protección, etc. Por otro lado, la mayoría de los edificios y construcciones existentes hoy en día sufren un grave deterioro debido al efecto producido por las pinturas graffiti $y$, sobre todo, durante la eliminación (limpieza) de éstas $(1,2)$.

Uno de los aspectos que se abordan tanto para los monumentos arquitectónicos como para los de uso común es la utilización de recubrimientos superficiales que sean capaces de producir al menos dos tipos de efectos sobre el material a recubrir: éstos son la protección y evitar el deterioro. Es decir, los tratamientos superficiales deben proteger al material frente a agresiones externas "premeditadas" como son los graffiti, carteles pegados, etc., y, por otro lado, deben evitar el deterioro medioambiental causado por el ambiente en donde está situada la construcción (3).

Son muchos los compuestos químicos que se han utilizado para recubrir a los materiales utilizados en la construcción (ya sean éstos correspondientes a monumentos del Patrimonio Nacional, como cualquier otro civil), estando entre ellos los oligosiloxanos, siloxanos, alcoxisilanos, microceras vegetales y las resinas (acrílicas y de metacrilato). Además de estos compuestos, están los disolventes empleados que pueden ser acuosos u orgánicos $(4,5,6)$.

Los estudios realizados sobre la utilización de estos compuestos para recubrir materiales de construcción y determinar cuál de ellos es el más apropiado, se han realizado, generalmente, desde el punto de vista del resultado final en cuanto a la calidad de la protección, el color, etc., así como desde el punto de vista de la porosidad final que queda en el material pétreo $(7,8$, 9). Sin embargo existen muy pocos estudios relacionados con las características superficiales de dichos materiales $y$, en particular, de su energía superficial. Es conocido que en muchos casos es esta energía superficial la que va a dar lugar a una mayor o menor interacción con la capa del compuesto utilizado como recubrimiento protector. Además, la temperatura a la que se aplique dicho compuesto puede influir, en gran medida, en alcanzar una mayor o menor interacción con la superficie y, por ello, mejorar o no la calidad de la protección.

En este trabajo se ha llevado a cabo un análisis de las características superficiales de cuatro materiales utilizados en la construcción de edificios, tanto arquitectónicos como de uso común. Dichos materiales han sido: ladrillo cara vista, granito, mármol y arenisca. La caracterización de la energía superficial se ha llevado a cabo mediante cromatografía inversa en fase gas a dilución infinita (IGC-ID).
The action taken includes restoration, conservation, rehabilitation, protection and so on. Furthermore, most buildings and structures standing today are subject to severe deterioration due to the effect of spray paint graffiti and the processes involved in its removal (cleaning) $(1,2)$.

One of the possible solutions for both architectural monuments and ordinary buildings is the use of surface coatings to protect the substrate and prevent its deterioration. In other words, surface treatments should protect the material from "premeditated" external aggression such as graffiti, bill posting and so on, as well as prevent the environmental deterioration caused by weathering (3).

The many chemical compounds used to coat construction materials (whether on heritage monuments or normal buildings) include oligosiloxanes, alcoxysilanes, plant microwax and (acrylic and methacrylate) resins. These compounds are generally dissolved in aqueous or organic solvents $(4,5,6)$.

The studies conducted on the use of these compounds to determine which provides the most suitable coating for construction materials have usually been conducted from the standpoint of the final result in terms of quality of protection, colour and so on, along with final stone porosity $(7,8,9)$. And yet there are very few studies on the surface characteristics of such materials, particularly their surface energy, which is known to often be the underlying cause of the greater or lesser interaction between the substrate and the compound used as a protective coating. Moreover, the temperature at which a compound is applied may have a significant impact on the degree of interaction with the surface and therefore its protective potential.

In the present study, an analysis was conducted of the surface characteristics of four materials used to build both architectural and ordinary structures. The materials studied were: fair-face brick, granite, marble and sandstone. Surface energy was determined with inverse gas chromatography at infinite dilution (IGC-ID). 


\section{EXPERIMENTAL}

De los cuatro materiales estudiados, la arenisca, mármol y granito han sido suministrados por la empresa CPA, S.A., y el ladrillo es común del tipo "cara vista". Estos materiales son habitualmente utilizados en construcciones o bien materiales sobre los que se llevan a cabo restauraciones.

La caracterización de la energía superficial se ha realizado mediante IGC-ID. Para ello se ha utilizado un cromatógrafo Perkin-Elmer Sigma 2 con detector de ionización de llama. Las columnas cromatográficas fueron preparadas empaquetando columnas de teflón de $3 \mathrm{~mm}$ de diámetro interior con partículas de tamaños comprendidos entre 0,2 y $0,3 \mathrm{~mm}$ de los materiales a analizar. Las moléculas utilizadas para la caracterización fueron compuestos que interaccionan de formas distintas con cualquier tipo de superficie, en la Tabla 1 se recogen dichos compuestos y las características de los mismos. Para las inyecciones de los compuestos sonda se utilizó una jeringa Hamilton de $1 \mu \mathrm{l}$. Se realizaron varias inyecciones para cada sonda y cada temperatura de análisis.

\section{TEORÍA DE LA CROMATOGRAFÍA INVERSA GAS-SÓLIDO}

Cuando la adsorción se realiza a dilución infinita la interacción entre las moléculas adsorbidas es nula y, por lo tanto, sólo tienen lugar las interacciones con la superficie del sólido. En estas condiciones se puede aplicar la Ley de Henry. La energía libre estándar que se produce cuando un mol de una molécula sonda se transfiere desde el estado gas a un estado adsorbido está relacionada con el volumen de retención neto $\mathrm{V}_{\mathrm{N}}$ según:

\section{EXPERIMENTAL}

Of the four materials studied, the sandstone, marble and granite were supplied by CPA, S.A. and the brick used was of the ordinary "fair face" type. All are materials commonly used in construction or found in restoration work.

The surface energy was determined with IGC-ID techniques using a Perkin-Elmer Sigma 2 chromatograph with a flame ionization detector and teflon columns having a $3 \mathrm{~mm}$ internal diameter. These were packed with the material to be analyzed, ground to a particle size ranging from 0.2 to $0.3 \mathrm{~mm}$. The characteristics of the probe molecules - compounds that interact in different ways with any type of surface- are listed in Table 1. Each probe compound was injected several times at each temperature with a $1-\mu$ l Hamilton syringe.

\section{INVERSE GAS CHROMATOGRAPHY THEORY}

Since the interaction between the adsorbed molecules is nil at infinite dilution, the only interactions taking place are on the surface of the solid. Under these conditions Henry's law applies. The standard free energy generated when one mol of a probe molecule is transferred from the gaseous to an adsorbed state is related to net retention volume $V_{N}$ as follows:

$$
\Delta \mathrm{G}_{\mathrm{A}} 0=-\mathrm{RT} \ln \left(\mathrm{V}_{\mathrm{N}}\right)+\mathrm{C}
$$

Tabla 1 / Table 1

Características de las moléculas sonda utilizadas Characteristics of the probe molecules used

\begin{tabular}{|c|c|c|c|c|c|}
\hline $\begin{array}{l}\text { Molécula } \\
\text { Molecule }\end{array}$ & $\begin{array}{l}\text { Nomenclatura } \\
\text { Nomenclature }\end{array}$ & DN (kcal.mol-1) & AN & AN* (kcal.mol-1) & $\begin{array}{l}\text { Carácter } \\
\text { Character }\end{array}$ \\
\hline n-pentano / n-pentane & $\mathrm{C5}$ & 0 & 0 & 0 & Neutro / Neutral \\
\hline n-hexano / n-hexane & $\mathrm{C} 6$ & 0 & 0 & 0 & Neutro / Neutral \\
\hline n-heptano / n-heptane & $\mathrm{C} 7$ & 0 & 0 & 0 & Neutro / Neutral \\
\hline n-octano / n-octane & $\mathrm{C} 8$ & 0 & 0 & 0 & Neutro / Neutral \\
\hline Cloroformo / Cloroform & $\mathrm{CL}$ & 0 & 23.1 & 5.4 & Ácido / Acid \\
\hline Benceno / Bencene & $\mathrm{BZ}$ & 0.1 & 8.0 & 0.17 & Ácido / Acid \\
\hline Acetona / Acetone & $\mathrm{AC}$ & 17.0 & 12.5 & & Neutro / Neutral \\
\hline Acetato de etilo / Ethyl acetate & $\mathrm{AE}$ & 17.1 & 9.3 & 1.5 & Neutro / Neutral \\
\hline Dietiléter / Diethyl-ether & $\mathrm{DE}$ & 19.2 & 3.9 & 1.4 & Básico / Basic \\
\hline Tetrahidrofurano / Tetrahydrofuran & THF & 20.0 & 8.0 & 0.5 & Básico / Basic \\
\hline
\end{tabular}


donde $T$ es la temperatura de la columna, $\mathrm{R}$ es la constante de los gases, $C$ es una constante que depende del estado de referencia y de la superficie específica del sólido.

La energía superficial, $\gamma_{S}$, es una medida de la interacción entre un sólido y el medio (sólido, líquido o gas) y se puede dividir en dos términos (10):

$$
\gamma_{S}=\gamma_{S}^{d}+\gamma_{S}^{P}
$$

donde $\gamma_{S}{ }^{d}$ representa la componente no específica o dispersiva, y $\gamma_{S}{ }^{P}$ es la componente específica o polar de la superficie. Ambas componentes se pueden determinar mediante IGC-ID, tal como se comenta a continuación.

En una primera aproximación, la energía libre de adsorción $\Delta G_{A} 0$ se puede relacionar con el trabajo de adhesión, $\mathrm{W}_{\mathrm{A}}$, entre la molécula de vapor (adsorbato) por unidad de área según la Ecuación siguiente (10): where $T$ is the column temperature, $R$ the universal gas constant, and $C$ a constant that depends on the reference status and the specific surface of the solid.

Surface energy, $\gamma_{S}$ a measure of the interaction between a solid and the medium (solid, liquid, gas), can be divided into two terms (10):

where $\gamma_{S}{ }^{d}$ represents the non-specific or dispersive component and $\gamma_{S}^{P}$ the specific or polar component of the surface. Both components may be determined with IGCID as discussed below.

In a first approximation, free adsorption energy $\Delta G_{A}{ }^{0}$ can be related to the work of adhesion, $W_{A}$, between the vapour molecule (adsorbate) and the substrate per unit of area in accordance with the following equation (10):

$$
\Delta \mathrm{G}_{\mathrm{A}}^{0}=\mathrm{N} \cdot a \cdot \mathrm{W}_{\mathrm{A}}=\mathrm{W}_{\mathrm{A}}^{\mathrm{d}}+\mathrm{W}_{\mathrm{A}}^{\mathrm{P}}
$$

donde $\mathrm{N}$ es el número de Avogadro, a es el área superficial de una molécula sonda adsorbida, y los superíndices $d$ y $P$ indican dispersiva y polar, respectivamente.

\section{Componente Dispersiva de la Energía Libre Superficial}

Cuando moléculas sonda no polares como los n-alcanos se emplean como adsorbatos en IGC-ID, el trabajo de adhesión está dominado por las interacciones dispersivas en la interfase, el término polar es cero y el trabajo de adhesión, Ecuación [3], toma la forma:

$$
W_{A}=\left(\gamma_{S}^{d} \cdot \gamma_{L}^{d}\right)^{1 / 2}
$$

donde $\gamma_{L}{ }^{d}$ es la componente dispersiva de la tensión superficial del líquido (sonda).

Combinando las ecuaciones anteriores, $\gamma_{S}{ }^{d}$ se puede calcular a través del volumen de retención neto, $V_{N}$, de una serie de $n$-alcanos $\left(\mathrm{C}_{n} \mathrm{H}_{2 n+2}\right)$ por medio de la siguiente Ecuación (11):

$$
\gamma_{\mathrm{S}}^{\mathrm{d}}=\left[\mathrm{R} \operatorname{Tn}\left(V_{\mathrm{n}+1} / V_{\mathrm{n}}\right)\right]^{2} /\left[4\left(\mathrm{~N} \cdot \mathrm{a}_{\mathrm{CH} 2}\right)^{2} \gamma_{\mathrm{CH} 2}\right]
$$

donde $\mathrm{a}_{(-\mathrm{CH} 2-)}$ es el área ocupada por un grupo metileno $\left(\mathrm{CH}_{2}\right)$ la cual es $0,06 \mathrm{~nm}^{2}, V_{\mathrm{n}+1}$ y $V_{\mathrm{n}}$ son los volúmenes de retención netos de $n$-alcanos que posean $n+1$ y $n$ átomos de carbono, respectivamente, y $\gamma_{(-\mathrm{CH} 2-)}$ es la energía superficial de un sólido que estuviera formado únicamente por grupos metileno. where $N$ is Avogrado's number, $a$ is the surface area of an adsorbed probe molecule and the superscripts $\mathrm{d}$ and $\mathrm{P}$ indicate dispersive and polar, respectively.

\section{Dispersive Component of Surface Free Energy}

When non-polar probe molecules such us n-alkanes are used as adsorbates in IGC-ID, work of adhesion (Equation [3]), characterized by a prevalence of dispersive interactions at the interface and a zero polar term, adopts the following form:

where $\gamma_{L}{ }^{d}$ is the dispersive component of the surface tension of the (probe) liquid.

If the above equations are combined, $\gamma_{S}{ }^{d}$ can be calculated from the net retention volume, $V_{N}$, of a series of $n$-alkanes $\left(\mathrm{C}_{n} \mathrm{H}_{2 n+2}\right)$ from the following Equation (11): where $a_{(-\mathrm{CH} 2-)}$ is the area occupied by a methylene group $\left(\mathrm{CH}_{2}\right)$, i.e., $0.06 \mathrm{~nm}^{2}, \mathrm{~V}_{n+1}$ and $V_{n}$ are the net retention volumes of the $n$-alkanes having $n+1$ and $n$ carbon atoms, respectively, and $\gamma_{\left(-\mathrm{CH}_{2}\right)}$ is the surface energy of a solid consisting solely of methylene groups. 


\section{Interacciones Polares. Componentes ácido-base de la energía superficial}

Cuando en la columna cromatográfica se inyectan moléculas polares, en la superficie del sólido tienen lugar tanto interacciones dispersivas como específicas. Así la Ecuación [3] ahora toma la forma:

\section{Polar interactions. Acid-base components of the surface energy}

When polar molecules are injected into a chromatographic column, both dispersive and specific interactions take place on the surface of the solid. Under these conditions Equation [3] therefore adopts the following form:

$$
W_{A}=2\left(\gamma_{S}{ }^{d} \cdot \gamma_{L}^{d}\right)^{1 / 2}+2\left(\gamma_{S}^{P} \cdot \gamma_{L}^{P}\right)^{1 / 2}
$$

Y por el mismo motivo, la energía libre de adsorción se puede expresar como:
And for the same reason, adsorption free energy can be expressed as follows:

$$
\Delta G_{A}^{0}=\Delta G_{A}^{d}+\Delta G_{A}^{P}
$$

donde $\Delta G_{\mathrm{A}}$ d y $\Delta G_{\mathrm{A}}{ }^{\mathrm{P}}$ son las contribuciones dispersiva y polar, respectivamente, a la energía libre de adsorción. $A$ fin de poder determinar $\Delta G_{A}{ }^{P}$ por IGC-ID es necesario eliminar $\Delta G_{A}$ d de $\Delta G_{A}{ }^{P}$. Para ello se representa $\Delta G_{A}{ }^{0}$ frente a una propiedad físico-química que refleje la capacidad de las moléculas para intercambiar interacciones dispersivas con la superficie. Entre las distintas propiedades posibles una de las más utilizadas es $(h v)^{1 / 2} a_{0}$, siendo hv el potencial de ionización de la molécula y $\mathrm{a}_{0}$ la polarizabilidad de inducción molar (12).

\section{RESULTADOS Y DISCUSIÓN}

\subsection{Caracterización general}

Los materiales estudiados se analizaron previamente mediante difracción de rayos $x(D R X)$ y espectroscopía infrarroja (FT-IR). Los resultados de DRX mostraron que el mármol y la arenisca contenían difracciones originadas por calcita, conteniendo además la arenisca difracciones debidas a la presencia de dolomita y de cuarzo. Por otro lado, el granito y el ladrillo contenían difracciones características del cuarzo, conteniendo además el granito pequeñas difracciones debidas a feldespato cálcico (plagioclasa) (13). Los espectros FT-IR corroboraron estos resultados.

En relación con la caracterización de la porosidad de estos materiales se observó que el granito prácticamente no poseía porosidad, mientras que los otros tres materiales poseían poros de tamaños medios diferentes, siendo mayor para el ladrillo $(510 \mathrm{~nm})$, seguido por el mármol $(70 \mathrm{~nm})$ y, finalmente, la arenisca $(65 \mathrm{~nm})$.

\subsection{Energía dispersiva}

Las Figuras 1 y 2 muestran la variación del tiempo de retención de distintos n-alcanos en función de la temperatura de análisis y del tipo de material analizado. Como where $\Delta G_{A}{ }^{d}$ and $\Delta G_{A}{ }^{P}$ are the dispersive and polar contributions, respectively, to adsorption free energy. But the $\Delta G_{A}{ }^{d}$ component must be eliminated to determine $\Delta G_{A}{ }^{P}$ with IGC-ID. To do so, $\Delta G_{A}{ }^{0}$ is graphed against a physical-chemical property reflecting the capacity of molecules to interact dispersivelt with the surface. One of the properties most frequently used for this purpose is $(h v)^{1 / 2} a_{0}$, where $h v$ is the ionization potential of the molecule and $a_{0}$ molar induction polarizability (12).

\section{RESULTS AND DISCUSSION}

\subsection{General characterization}

The materials studied were pre-analyzed by means of $X R D$ and infrared spectroscopy (FTIR). The XRD diffraction patterns showed that marble and sandstone contained calcite, and that dolomite and quartz were also present in the latter. Granite and brick, in turn, showed peaks typical of quartz, and the granite also had small amounts of calcium feldspar (plagioclase) (13). The FTIR spectra confirmed these results.

When the materials were characterized for porosity, the granite was found to be essentially non-porous, while the other three materials had different mean pore sizes: the largest was observed in brick $(510 \mathrm{~nm})$, followed by marble $(70 \mathrm{~nm})$ and sandstone $(65 \mathrm{~nm})$.

\subsection{Dispersive energy}

Figures 1 and 2 show the variation in retention time for the different $n$-alkanes depending on the test temperature and type of material analyzed. As might be expected, 
es de esperar, el $V_{N}$ aumenta con el tamaño de la molécula del n-alcano debido a que aumenta el número de grupos metileno en la molécula. A partir de la pendiente de cada una de las rectas, se puede obtener la componente de London, o energía dispersiva, de la energía superficial de acuerdo con la Ecuación [5]. Esta energía dispersiva se determinó a las tres temperaturas de análisis, obteniéndose en todos los casos líneas rectas con coeficientes de regresión superiores a 0,999. En la Tabla 2 se recogen los valores obtenidos para la energía dispersiva de los materiales estudiados.

Según los resultados de la Tabla 2 se puede comprobar que la arenisca presenta el mayor valor de la energía dispersiva superficial, valor que es próximo al obtenido para materiales de tipo caliza (14). A continuación, con un menor valor de la energía dispersiva, está el granito, seguido por el ladrillo y, finalmente, el mármol. En general los valores obtenidos son similares a los dados en la bibliografía para materiales inorgánicos de baja superficie específica y sin mesoporosidad (15-17).
$V_{N}$ increased with the size of the n-alkane molecule due to the larger number of methylene groups. The London or dispersive energy component of the surface energy can be found from the slope of the lines and Equation [5]. Dispersive energy was determined by this method at the three temperatures at which IGC was run. The results in all cases were straight lines with regression coefficients higher than 0.999. The dispersive energy values obtained for the materials studied are given in Table 2.

According to the results in Table 2, sandstone exhibited the highest surface dispersive energy value, which was, moreover, close to the value reported for limestone-type materials (14). Granite showed a smaller value of dispersive energy, followed in turn by brick and finally marble. As a general rule, the values found were similar to those reported in the literature for non-mesoporous, inorganic materials with low specific surface values (15-17).

Tabla 2 / Table 2

Energía dispersiva de la superficie de materiales de construcción Surface dispersive energy in construction materials

\begin{tabular}{|c|c|c|c|c|c|}
\hline & $\begin{array}{c}\text { Ladrillo } \\
\text { Brick }\end{array}$ & $\begin{array}{l}\text { Granito } \\
\text { Granite }\end{array}$ & $\begin{array}{l}\text { Arenisca } \\
\text { Sandstone }\end{array}$ & $\begin{array}{l}\text { Mármol } \\
\text { Marble }\end{array}$ & $\mathbf{T}(\mathrm{K})$ \\
\hline \multirow{4}{*}{$\gamma_{s}^{d}\left(m J \cdot m^{-2}\right)$} & 39.65 & 44.18 & 56.55 & 35.08 & 313.15 \\
\hline & 29.9 & 36.08 & 46.94 & 31.37 & 326.15 \\
\hline & 29.31 & 29.38 & 47.15 & 24.85 & 333.15 \\
\hline & 32.95 & 36.55 & 50.21 & 30.43 & Media \\
\hline $\mathrm{s}_{\mathrm{S}}^{\mathrm{d}}\left(\mathrm{mJ} \cdot \mathrm{m}^{-2} \mathrm{~K}^{-1}\right)$ & 0.52 & 0.74 & 0.47 & 0.51 & \\
\hline $\mathrm{h}_{\mathrm{S}}^{\mathrm{d}} \quad\left(\mathrm{mJ} \cdot \mathrm{m}^{-2}\right)$ & 200 & 276 & 202 & 196 & \\
\hline$\%\left(\mathrm{~d} \gamma_{S}{ }^{d} / d T\right) / \gamma_{S}{ }^{d}$ & 1.58 & 2.02 & 0.94 & 1.68 & \\
\hline
\end{tabular}

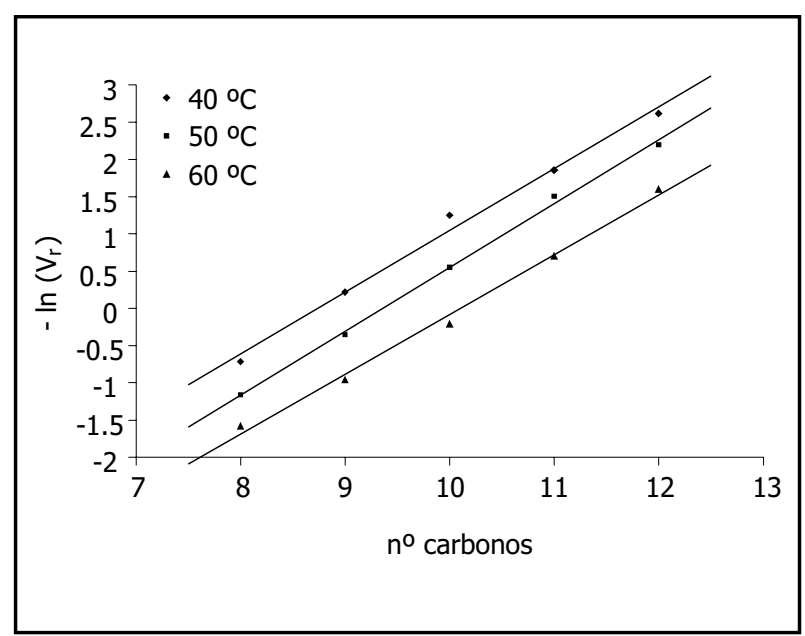

Figura 1. Representación del volumen de retención de $n$-alcanos en ladrillo.

Figure 1. Retention volume of $n$-alkanes in brick.

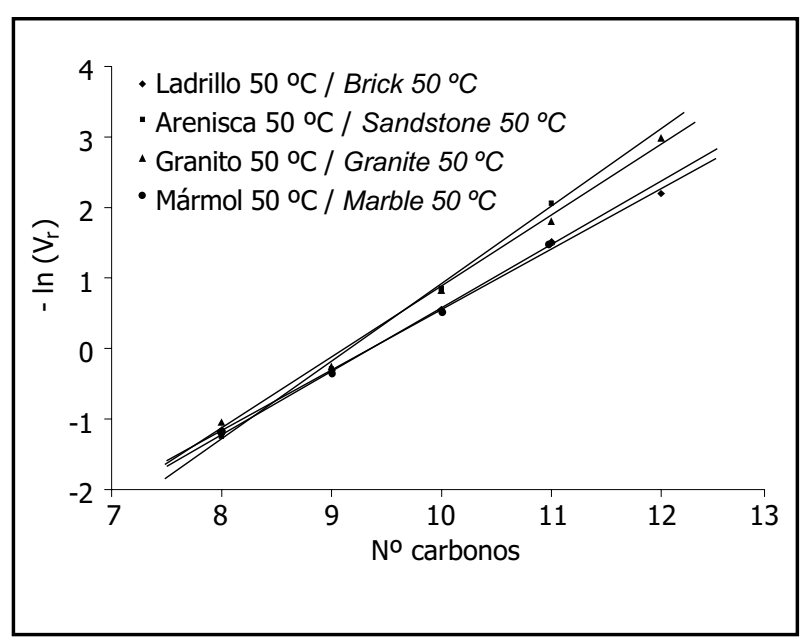

Figura 2. Representación del volumen de retención de n-alcanos en materiales de construcción.

Figure 2. Retention volume of $n$-alkanes in construction materials. 
Como puede verse en la Tabla $2, \gamma_{S}{ }^{d}$ disminuye con el aumento de la temperatura de análisis, resultado que está de acuerdo con el bien conocido efecto de la temperatura en el comportamiento de las interacciones intermoleculares (18). Esta dependencia de $\gamma_{S}{ }^{\mathrm{d}}$ con $T$ se presenta en la Ecuación [8]:

$$
\gamma_{S}^{d}=h_{S}^{d}-T s_{S}^{d}
$$

donde $h_{S}{ }^{\mathrm{d}}$ y $S_{S}{ }^{\mathrm{d}}$ son la entalpía y entropía dispersivas, respectivamente. En general, el gradiente de temperatura de $\gamma_{S}{ }^{d}$ caracteriza la capacidad que tiene la superficie para intercambiar interacciones dispersivas con otras superficies. La influencia de la temperatura en los materiales de construcción estudiados se puede cuantificar utilizando el gradiente de temperatura relativo de $\gamma_{S}{ }^{\mathrm{d}}$ expresado como un porcentaje según la Ecuación siguiente (19):

$$
-\left(\mathrm{d} \gamma_{S}^{\mathrm{d}} / \mathrm{d} T\right) / \gamma_{S}^{\mathrm{d}}
$$

donde $d \gamma_{S} d / d T$ es la pendiente de la representación lineal existente entre $\gamma_{S}{ }^{d}$ y la temperatura de medida. Los resultados de las Ecuaciones [8] y [9] para los materiales estudiados se dan también en la Tabla 2.

De acuerdo con los datos de $\left(\mathrm{d} \gamma_{S} \mathrm{~d} / \mathrm{dT}\right) / \gamma_{S}{ }^{\mathrm{d}}$ dados en la Tabla 2, se observa que el granito es el material en el que mayor efecto produce la temperatura a la hora de interaccionar con otros compuestos, por lo que podría decirse que a la hora de depositar una capa de material antivandálico debe tenerse muy en cuenta la temperatura del granito, así como la de deposición. Por el contrario, el valor más pequeño lo presenta la arenisca con lo que este material es el que menor influencia tiene la temperatura cuando otro es depositado sobre él. Respecto al mármol, éste presenta un valor de $\left(\mathrm{d} \gamma_{\mathrm{S}} \mathrm{d} / \mathrm{dT}\right) /$ $\gamma_{S}{ }^{d}$ relativamente elevado comparado con el de la arenisca, a pesar de que ambos poseen composición química y mineralógica, así como porosidades bastante parecidas, de lo que se deduce que, si a la hora de depositar un material antivandálico en ambos materiales solamente se tienen en cuenta tales propiedades (composición, porosidad, etc.), los resultados pueden ser completamente diferentes si el material antivandálico intercambia interacciones, fundamentalmente dispersivas, con la superficie del sólido. En el caso de que dichas interacciones sean también del tipo ácido-base, es necesario realizar su caracterización tal y como ahora se muestra.

\subsection{Energía específica ácido-base}

Las propiedades ácido-base de los materiales de construcción estudiados también han sido determinadas mediante IGC-ID. Para ello se han utilizado las moléculas sonda recogidas en la Tabla 1 . Las Figuras 3 y 4
As Table 2 shows, $\gamma_{S}^{d}$ decreases as test temperature increases, in accordance with the well-known effect of temperature on intermolecular interactions (18). This dependence of $\gamma_{S}{ }^{d}$ on $T$ can be expressed as follows [8]:

where $h_{S}{ }^{d}$ and $s_{S}{ }^{d}$ are dispersive enthalpy and entropy, respectively. Inasmuch as the temperature gradient $\gamma_{S}{ }^{d}$ characterizes the dispersion interaction capacity of the surface, the effect of temperature on the construction materials studied can be quantified from the relative temperature gradient $\gamma_{S}{ }^{d}$, expressed as a percentage, as per the following Equation (19):

where $d \gamma_{S}{ }^{d} / d T$ is the slope of the line representing the relationship between $\gamma_{S}{ }^{d}$ and the mean temperature. The solutions for Equations [8] and [9] for the materials studied are also given in Table 2.

Further to the $\left(d \gamma_{S}{ }^{d} / d T\right) / \gamma_{S}{ }^{d}$ data shown in Table 2, granite is the material most strongly affected by temperature in its interactions with other compounds. The inference is that the temperature of application and of the granite substrate is a relevant consideration in anti-graffiti paint treatment. Sandstone, with the smallest value, is the material that would be least affected by temperature when coated with such substances. Marble, in turn, had a relatively high value compared to sandstone, despite their similar chemical and mineralogical composition and porosities. This finding implies that if these are the only properties (composition, porosity and so on) considered when applying an anti-graffiti coating, the results obtained for the two substrates may be completely different if the interaction between the substance and the surface of the solid is essentially dispersive. Where such interactions are also polar, they must be characterized as shown below.

\subsection{Acid-base specific energy}

The acid-base properties of the construction materials studied were also determined with IGC-ID. The probe molecules listed in Table 1 were used for this purpose. Figures 3 and 4 show the graphs for $V_{N} v s$. (hv $)^{1 / 2} a_{0}$ 
muestran las representaciones de $V_{N} v s$. $(h v)^{1 / 2} a_{0}$ (polarizabilidad de deformación molar) para los materiales mármol y granito, para los otros dos materiales las representaciones fueron similares con la diferencia de la posición de los volúmenes de retención de los vapores específicos. Se ha elegido la representación de dichos volúmenes frente a la polarizabilidad molecular, ya que esta propiedad es independiente de la temperatura $y$, por ello, se puede usar en un amplio intervalo de temperaturas (desde -100 a unos $300^{\circ} \mathrm{C}$ ) (20). Ambas figuras muestran una línea recta para los n-alcanos y una desviación de cada uno de los vapores específicos respecto a dicha línea. De acuerdo con la Ecuación [7], los valores de $-\Delta G_{A} P$ para cada molécula específica se pueden obtener a partir de las citadas desviaciones.

Cada valor de $-\Delta G_{A}{ }^{P}$ se obtuvo para cada una de las temperaturas de análisis, y de forma similar a lo que ocurría con la componente dispersiva $\gamma_{S}{ }^{d}$, estos valores dependen de la temperatura, por lo que contienen la contribución entrópica correspondiente. Por lo tanto, es necesario eliminar dicha contribución utilizando la entalpía específica de acuerdo a la Ecuación siguiente:

$$
\Delta G_{\mathrm{A}} \mathrm{P}=\Delta H_{\mathrm{A}} \mathrm{P}-\mathrm{T} \Delta S_{\mathrm{A}}^{\mathrm{P}}
$$

The $-\Delta G_{A}{ }^{P}$ values were obtained for all the probe molecules and column temperatures. As in the case of the dispersive component $\gamma_{S}{ }^{d}$, these values were observed to have an entropic component, as they varied with temperature. That component had therefore to be eliminated using specific enthalpy in accordance with the following expression: (molar deformation polarizability) for marble and granite. The graphs for the other materials were similar, with the exception of the position of the specific vapour retention volumes. These volumes were plotted against molecular polarizability, for this property is independent of temperature and can therefore be used across a wide range of values (from -100 to around $300^{\circ} \mathrm{C}$ ) (20). Both figures show a straight line for $n$-alkanes and the deviations for each of the specific vapours. Further to Equation [7], the values of $-\Delta G_{A}{ }^{P}$ for each specific molecule can be obtained from such deviations.
A partir de la ordenada en el origen de la Ecuación [10] se han calculado los valores de $\Delta H_{A}{ }^{P}$, que ya se pueden utilizar para determinar las constantes ácidas y básicas de las superficies mediante la Ecuación siguiente (21):

$$
\Delta H_{\mathrm{A}}^{\mathrm{P}}=\mathrm{k}_{\mathrm{A}} \cdot \mathrm{DN}+\mathrm{k}_{\mathrm{B}} \cdot \mathrm{AN}
$$

donde los parámetros $\mathrm{k}_{\mathrm{A}}$ y $\mathrm{k}_{\mathrm{B}}$ representan la capacidad de la superficie sólida de actuar bien como ácido o como base respectivamente, y las constantes DN y AN de cada molécula sonda se han dado en la Tabla 1. En esta Ecuación se ha considerado que las características ácidas de la superficie interaccionan con la componente básica de cada molécula y las características básicas de la superficie con la ácida de la molécula. La Ecuación [11] es la de una recta en la que todo es conocido excepto $k_{A}$ y $k_{B}$. La Figura 5 muestra dicha representación.

Los valores de los parámetros ácido y básico, así como la relación ácido-base, se recogen en la Tabla 3 para los materiales de construcción estudiados.

De acuerdo con estos resultados, se puede decir que el mármol es el material con mayor carácter básico $\left(k_{B}=2,48\right)$, lo que coincide con su composición química, si bien también posee bastante carácter ácido $\left(k_{A}=1,87\right)$, debido a la presencia de grupos hidroxilo superficiales. En orden decreciente de basicidad está, a continuación del mármol, la arenisca, que, por poseer también carbonato
The values of $\Delta H_{A}{ }^{P}$ were calculated from the $y$-intercept in Equation [10]. These values can be used to determine the acid and base constants of the surfaces from the following Equation (21):

where the parameters $k_{A}$ and $k_{B}$ represent the capacity of the solid surface to act as an acid or a base, respectively, while the $D N$ and $A N$ constants for each probe molecule are given in Table 1. In this equation, the acid properties of the surface are assumed to interact with the alkaline component of each molecule, and the alkaline properties of the surface with its acid component. Equation [11] describes a straight line for which all the parameters except $k_{A} y k_{B}$ are known. The line is shown in Figure 5.

The values of the acid and base parameters and the acid-base ratio for the construction materials studied are given in Table 3.

According to these results, marble is the most basic material $\left(k_{B}=2.48\right)$, in accordance with its chemical composition, although the presence of surface hydroxyl groups also explains the presence of acidic activity $\left(k_{A}\right.$ $=1.87$ ). Sandstone, which also contains calcium carbonate in its composition, was the second most basic material studied. The lower acidity of sandstone with respect 


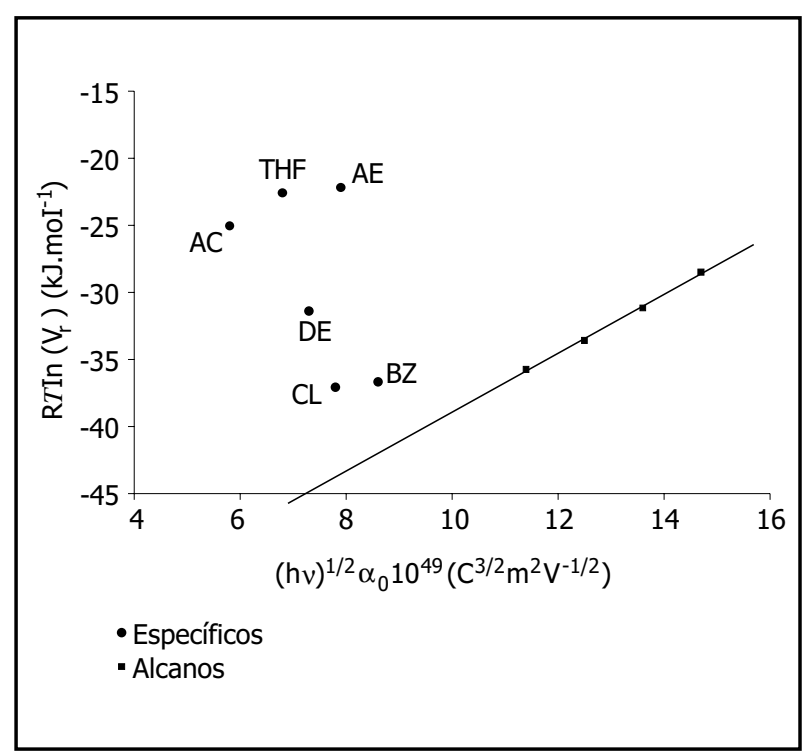

Figura 3. Representación del volumen de retención de diferentes moléculas sonda en mármol.

Figure 3. Retention volumes in marble for different probe molecules.

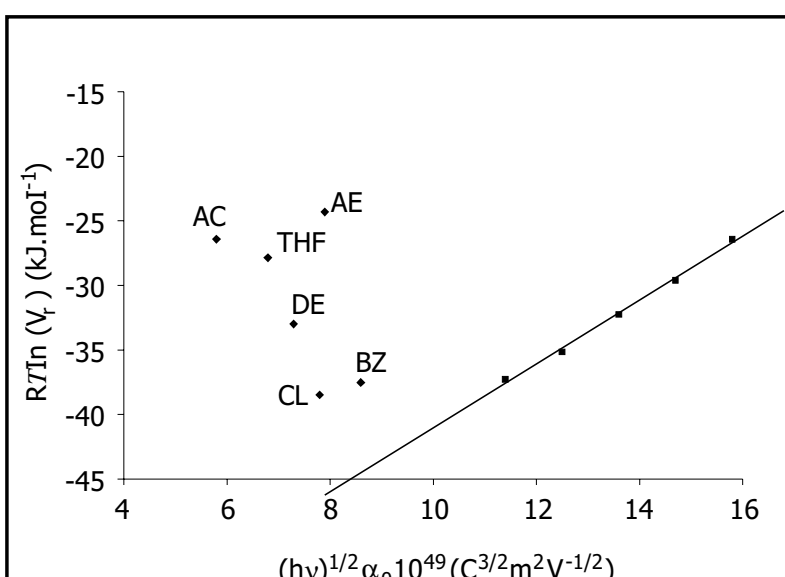

$(h v)^{1 / 2} \alpha_{0} 10^{49}\left(C^{3 / 2} m^{2} v^{-1 / 2}\right)$

- Específicos

- Alcanos

Figura 4. Representación del volumen de retención de diferentes moléculas sonda en granito.

Figure 4. Retention volumes in granite for different probe molecules.

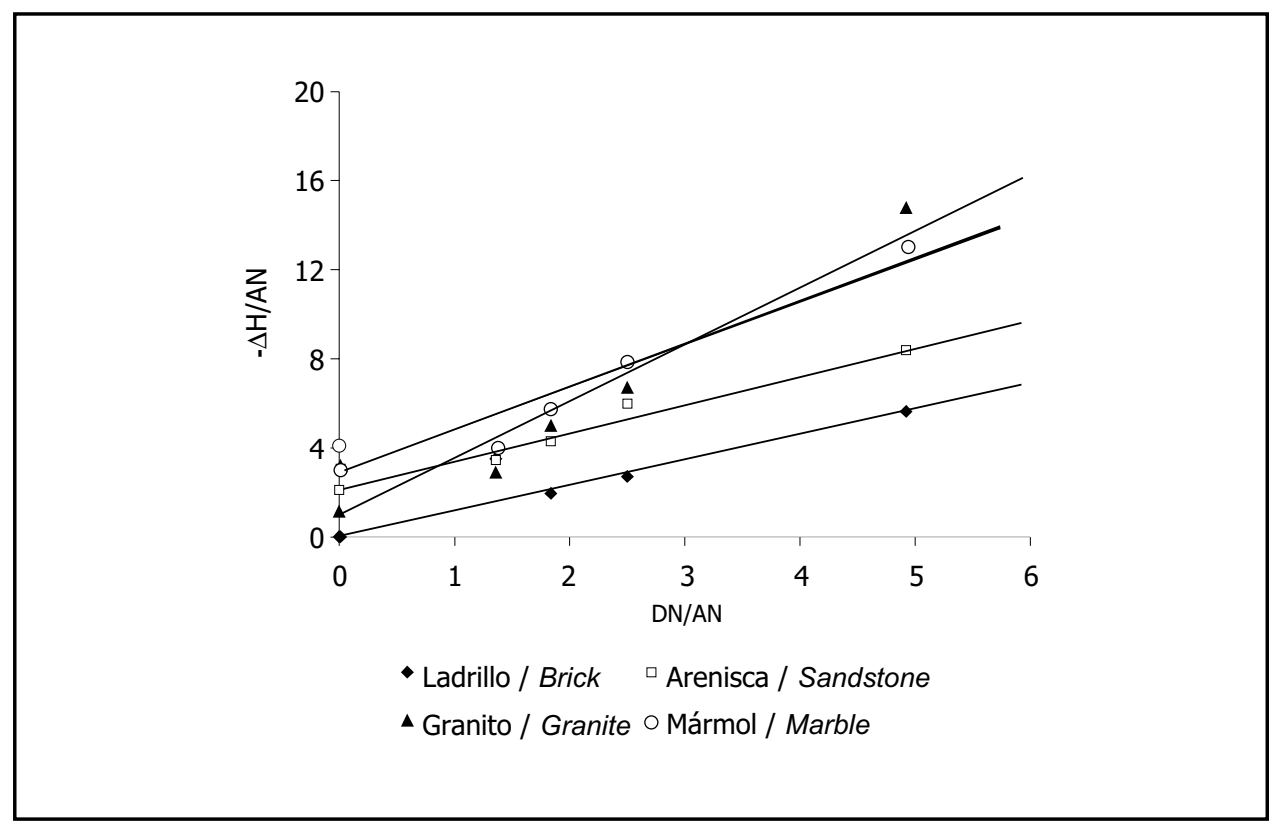

Figura 5. Determinación de las constantes ácido-base en materiales de construcción.

Figure 5. Determination of the acid-base constants in construction materials.

Tabla 3 / Table 3

Constantes ácida y básica de materiales de construcción Acid and base constants for construction materials

\begin{tabular}{|lcccc|}
\hline & Arenisca / Sandstone & Mármol / Marble & Granito / Granite & Ladrillo / Brick \\
\hline $\mathrm{k}_{\mathrm{A}}$ & 1.07 & 1.87 & 2.54 & 0.99 \\
\hline $\mathrm{kB}$ & 2.20 & 2.48 & 1.12 & 0.67 \\
\hline $\mathrm{k}_{\mathrm{A}} / \mathrm{kB}$ & 0.54 & 0.75 & 2.26 & 1.47 \\
\hline
\end{tabular}


cálcico en su composición, tiene dicho carácter básico. La menor acidez de la arenisca respecto al mármol debe estar originado por un menor contenido en grupos hidroxilo superficiales o bien que dichos grupos posean menor fuerza. Por el contrario, el material con mayor acidez es el granito, debido a la presencia de cuarzo y sílice en su composición, mientras que la cierta basicidad de este material es debida al bien conocido carácter de la sílice, la cual posee centros activos tanto ácidos como básicos $(16,19,22)$, así como a la presencia de mica, tal y como se comentó, mediante DRX. Finalmente, con menores valores de acidez y basicidad está el ladrillo, debido a que dicho material ha sido obtenido a alta temperatura y la mayor parte de los centros activos han sido eliminados durante la cocción. Los bajos valores obtenidos para el ladrillo están en concordancia con los materiales vitrificados $(22,23,24)$, lo que corrobora el efecto de la temperatura de cocción de dicho material.

En cuanto a la relación ácido-base en los cuatro materiales estudiados, la Tabla 3 muestra que los cuatro son anfóteros, pues poseen centros ácidos y básicos, si bien el granito y el ladrillo son fundamentalmente ácidos, mientras que la arenisca y el mármol son básicos. De nuevo decir que la presencia de este tipo de centros activos superficiales debe influir, en gran medida, en la interacción de los recubrimientos antivandálicos utilizados actualmente, pudiéndose dar el caso de que unos sirvan para unos tipos de materiales y otros para materiales distintos, a no ser que dichos materiales antivandálicos sean diseñados atendiendo a la naturaleza ácido-base de cada sólido en el que se van a depositar.

\section{CONCLUSIONES}

En este trabajo se ha puesto de manifiesto la utilidad de la cromatografía inversa gas-sólido a dilución infinita en la caracterización de la superficie de diferentes materiales de construcción: mármol, arenisca, granito y ladrillo. La energía de la superficie de estos materiales se ha dividido en dos componentes: dispersiva y ácidobase. Los valores medios de las energías dispersivas obtenidas han sido de 50,21, 36,55, 32,95 y 30,43 mJ.m-2 para arenisca, granito, ladrillo y mármol, respectivamente, valores que están de acuerdo con materiales inorgánicos macroporosos. Por otro lado, las energías específicas o ácido-base de estos materiales han mostrado que la arenisca y el mármol son fundamentalmente básicos, mientras que el granito y el ladrillo son ácidos, si bien todos los materiales poseen ambas características, se les puede considerar como anfóteros, ya que ninguna de las dos prevalece, en gran medida, sobre la otra. to marble must be due to a lower hydroxyl group content on its surface, or the lesser strength of such groups. Granite, in contrast, is the most acidic material, due to the presence of quartz and silica in its composition; this material also owes its alkaline content to the well-known existence of both acid and alkaline active centres (16, $19,22)$ in silica, and to the presence of mica, detected with XRD as mentioned above. Finally, brick exhibited the lowest acid and basic values, perhaps because most of the active centres in this material may be eliminated during firing. The low values obtained for brick are in accordance with findings for vitrified materials (22, 23, 24) corroborating the effect of high firing temperatures.

The acid-base ratio of the four materials studied shown in Table 3 shows that all four are amphoteric, because have both acid and alkaline centres, although granite and brick are essentially acid while sandstone and marble are mostly basic. Again, the presence of such active centres on the surface must have a substantial impact on the interaction with the anti-graffiti coatings presently in use. In this regard, some paints may be found to be effective with certain materials and different coatings with others, unless such products are designed to accommodate the acid-base nature of the specific solid to which they are to be applied.

\section{CONCLUSIONS}

This study has shown the utility of inverse gas chromatography at infinite dilution for characterizing the surface of different construction materials: marble, sandstone, granite and brick. The surface energy of these materials was divided into two components: dispersive and polar or acid-base. The mean values of the dispersive energies obtained were 50.21, 36.55, 32.95 and $30.43 \mathrm{~mJ} \cdot \mathrm{m}^{-2}$ for sandstone, granite, brick and marble, respectively, all of which are characteristic of macroporous inorganic materials. Moreover, the specific or acidbase energies of these materials showed sandstone and marble to be essentially basic and granite and brick to be acid. Nonetheless, as all of these materials exhibit both properties with neither prevailing over the other to any substantial extent, they can be regarded to be amphoteric. 


\section{AGRADECIMIENTOS}

Este trabajo ha sido realizado gracias a la financiación por parte del Ministerio de Educación y Cultura mediante el Proyecto CICYT MAT2003-08343. Los autores además agradecen a M. ${ }^{\mathrm{a}}$ T. Blanco-Varela las correcciones y sugerencias realizadas para mejorar este trabajo.

\section{ACKNOWLEDGEMENTS}

The present study was financed by the Ministry of Education and Science under CICYT Project MAT2003-08343. The authors wish to thank M.a T. Blanco-Varela for her helpful suggestions for improvements in the manuscript.

\section{BIBLIOGRAFÍA / BIBLIOGRAPHY}

(1) Arias, P, Herráez, J., Lorenzo, H. y Ordóñez, C.: "Control of structural problems in cultural heritage monuments using close-range photogrammetry and computer methods", Comput. Struct., vol. 83 (2005), pp. 1754-1766.

(2) Pegon, P., Pinto, A. V., Géradin, M.: "Numerical modelling of stone-block monumental structures", Comput. Struct., vol. 79 (2001), pp. $2165-2181$.

(3) Carreti, E. y Dei, L.: "Physicochemical characterization of acrylic polymeric resins coating porous materials of artistic interest", Prog. Org. Coat., vol. 49 (2004), pp. 282-289.

(4) Torraca, G.: Porous building materials-materials science for architectural conservation. Int. Cent. for the Study of the Preservation and the Restoration of Cultural Property (1981), pp. 64-66.

(5) Croci, G.: The conservation and structural restoration of architectural heritage, Southhampton, UK, Boston, USA: Computational Mechanics Publications, 1998, p. 68.

(6) Weaver, M. y Matero, F. G.: Conserving buildings-guide to techniques and materials. Wiley, New York, 1997, p. 133.

(7) Iñigo, A. C., Vicente, M. A. y Rives, V.: "Weathering and decay of granitic rocks: its relation to their pore network". Mechanics Mater., vol. 32 (2000), pp. 555-560.

(8) Lopez-Arce, P., García-Guinea, J.: "Weathering traces in ancient bricks from historic buildings", Build. Environ., vol. 40 (2005), pp. $929-941$.

(9) Lopez-Arce, P., García-Guinea, J., Gracia, M. y Obis, J.: "Bricks in historical buildings of Toledo City: characterisation and restoration", Mater. Charact., vol. 50 (2003), pp. 59-68.

(10) Fowkes, F. M.: Recent Advances in Adhesion. Gordon and Breach, New York, 1973.

(11) Schultz, J., Lavielle, L. y Martin, C.: "Surface Properties of Carbon Fibers by Inverse Gas Chromatograpy", J. Adhesion, vol. 23 (1987), pp. 45-60.

(12) Gutierrez, M. C., Rubio, J., Rubio, F. y Oteo, J. L.: "Inverse Gas Chromatography: a new approach to the estimation of specific interactions", J. Chrom. A., vol. 845, 53 (1999), pp. 53-66.

(13) Oteo, J. L., Elvira, M. R., Alonso, L. y Rubio, J.: "Tratamientos de protección superficial de materiales de construcción por nuevos materiales híbridos organo-inorgánicos multifuncionales", Bol. Soc. Esp. Ceram. Vidrio (2005). En imprenta.

(14) Shui, M.: "Polymer surface modification and characterization of particulate calcium carbonate fillers", App. Surf. Sci., vol. 220 (2003), pp. 359-366.

(15) Rubio, J., Rubio, F. y Oteo, J. L.: "Energía y heterogeneidad energética de la superficie del vidrio", Bol. Soc. Esp. Cerámica y Vidrio, vol. 36, no 5 (1997), pp. 485-495.

(16) Rodríguez, M. A., Rubio, J., Rubio, F., Liso M. J. y Oteo, J. L.: "Application of the Inverse Gas Chromatography to the Study of the Surface Properties of Slates", Clay. Clay Miner, vol. 45, no 5 (1997), pp. 670-680.

(17) Milonjic, S. K.: "Surface properties of metal ions modified silica", Colloids Surfaces A: Phys. Eng. Asp., vol. 149 (1999), pp. $461-466$.

(18) Peña-Alonso, R., Tamayo, A., Rubio, F. y Rubio, J.: "Influence of boron concentration on the surface properties of teos-pdms hybrid materials", J. Sol-Gel Sci. Tech., vol. 36 (2005), pp. 113-124.

(19) Bogillo, V. I., Shkilev, V. P. y Voelkel, A.: "Chemical Heterogeneity of Metal Oxide Surfaces as Studied by Inverse Gas Chromatography at Finite Concentrations", Ads. Sci. Tech., vol. 14 (1996), pp. 189-198.

(20) Donnet, J. B., Park, S. J. y Balard, H.: "Evaluation of Specific Interactions of Solid Surfaces by Inverse Gas Chromatography", Chromatographia, vol. 31, no 9/10 (1991), pp. 434-440.

(21) Hamieh, T., Nardin, M., Rageul-Lescou, M., Haidara, H. y Schultz, J.: "Study of acid-base interactions between some metallic oxides and model organic molecules", Colloids Surf. A., vol. 125 (1997), pp. 155-161.

(22) Rubio, F., Rubio, J. y Oteo, J. L.: "Surface Energy Changes of Heat Treated TEOS Derived Silica Xerogels", J. Sol-Gel Sci. Tech., vol. 10 (1997), pp. 31-44.

(23) Bautista, M. C., Rubio, J. y Oteo, J. L.: "Surface Thermodynamic Analysis of Cleaned Silicoaluminate Glass Fibres", J. Mater. Sci., vol. 30 (1995), pp. 1595-1600.

(24) Martín, L., Rubio, J. y Oteo, J. L.: "Caracterización de vidrio poroso por Cromatografía gaseosa y recubrimiento cero", Bol. Soc. Esp. Cerámica y Vidrio, vol. 31, no 3 (1992), pp. 233-237. 